\title{
The Effects of Site Characterization Activities on the Abundance of Ravens (Corvus corax) in the Yucca Mountain Area
}

\section{Civilian Radioactive Waste Management System \\ Management \& Operating Contractor}

B\&W Federal Eervices

Duke Engineering \& Services, Inc. E.R. Johnson Assoctates, inc. Fiuor Daniel, Inc. Framatome Cogerna Fuels integrated Resources Group WTERA, inc.

Prepared by:

TRW Emvironmentaf Eafety Systems Inc.
JK Research Associates, Inc.

KlewitParsons Brinckerhoff

Lawrence Berkeley Laboratory

Lawrence Livermore National Laboratory

Logicon RDA

Los Alamos National Laboratory

Morrison-Knudsen Corporation

Prepared for:

US. Department of Energy Office of Clvilian Radioactive Waste Management 1000 independence Avenue, S.W. Washington, D.C. 20565
SAC

Sandla National Laboratories

TRW Environmental Safety Systems Inc. Woodward-Clyde Federal Servlces Winston \& Strawn Cooperating Federal Agency: U.S. Geological Eurvey 
QA: N/A

Civilian Radioactive Waste Management System

Management and Operating Contractor

The Effects of Site Characterization Activities on the Abundance of Ravens (Corvus corax) in the Yucca Mountain Area

B00000000-01717-5705-00040

Aprii 27, 1998

Prepared for:

U.S. Department of Energy

Yucca Mountain Site Characterization Office

P.O. Box 30307

North Las Vegas, NV 89036-0307

Prepared by:

TRW Environmental Safety Systems Inc.

1180 Town Center Drive

Las Vegas, Nevada 89134

Under Contract Number

DE-AC08-91RW00134 
Civilian Radioactive Waste Management System

Management and Operating Contractor

The Effects of Site Characterization Activities on the Abundance of Ravens (Corvus cora) in the Yucca Mountain Area

April 27, 1998

Prepared by:

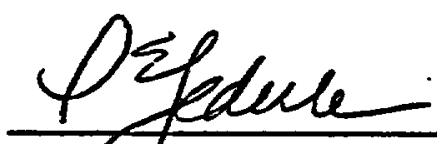

Patrick Lederle

Science Applications International Corporation

Gu e Milk

James M. Mueller

EG\&G Energy Measurements, Inc.

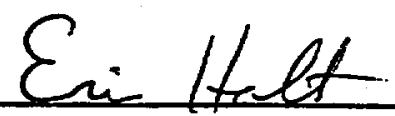

Eric A. Holt EG\&G Energy Measurements, Inc.

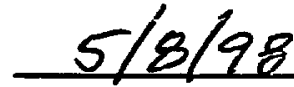

Date

$5 / 8 / 98$

Date

$5 / 8 / 98$

Date

Approved by:
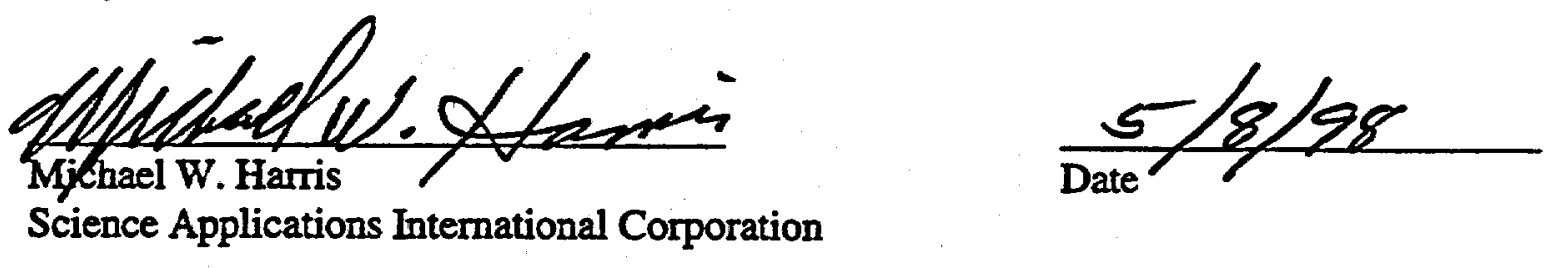


\section{ACKNOWLEDGMENTS}

Many individuals assisted with the Desert Tortoise Monitoring Program while employed by EG\&G Energy Measurements, Environmental Sciences Department, and contributed directly to this study by conducting raven surveys. Their help in collecting the data used in this study is appreciated.

R.G. Goodwin assisted with the management and summary of the hatchling data. C.A. Callison assisted with development of graphics. D.S. Ambos summarized the weather data from Yucca Mountain and Beatty.

W.I. Boarman, J.L. Boone, A.S. Dodd, C.D. Powers, D.L. Rakestraw, and K.R. Rautenstrauch reviewed and improved the draft report. T.B. Doerr, R.A. Green, W.K. Ostler, and D.L. Rakestraw provided administrative support.

Tortoise carcasses were collected, and hatchlings were radiomarked and monitored under permits PRT-683011 and PRT-781234 from the U.S. Fish and Wildlife Service, and S-0446, S-1595, S3108, S-5041, S-6941, and S-9060 from the Nevada Division of Wildlife. Data described in this report were collected under contracts DE-AC08-88NV10617 and DE-AC08-93NV11265 to EG\&G Energy Measurements, Inc.

\section{DISCLAIMER}

This report was prepared as an account of work sponsored by an agency of the United States Government. Neither the United States nor any agency thereof, nor any of their employees, makes any warranty, expressed or implied, or assumes any legal responsibility for the accuracy, completeness, or usefullness of any information, apparatus, product, or process disclosed, or represents that its use would nor infringe privately owned rights, Reference herein to any specific commercial product, process, or service by trade name, trademark, manufacturer, or otherwise, does not necessarily constitute or imply its endorsement, recommendation, or favoring by the United States Government or any agency thereof. The views and opinions of authors expressed herein do not necessarily state or reflect those of the United States Government or any agency thereof. 


\section{EXECUTIVE SUMMARY}

In response to the Nuclear Waste Policy Act of 1982 and the Nuclear Waste Policy Amendments Act of 1987, the U.S. Department of Energy (DOE) developed and is implementing the Yucca Mountain Site Characterization Project. Raven abundance was measured from August 1991 through August 1995 along treatment and control routes to evaluate whether site characterization activities resulted in increased raven abundance at Yucca Mountain. This study fulfills the requirement set forth in the incidental take provisions of the Biological Opinion that DOE monitor the abundance of ravens at Yucca Mountain.

Ravens were more abundant at Yucca Mountain than in the control area, and raven abundance in both areas increased over time. However, the magnitude of differences between Yucca Mountain and control surveys did not change over time, indicating that the increase in raven abundance observed during this study was not related to site characterization activities. Increases over time on both Yucca Mountain and control routes are consistent with increases in raven abundance in the Mojave Desert reported by the annual Breeding Bird Survey of the U.S. Fish and Wildlife Service.

Evidence from the Desert Tortoise Monitoring Program at Yucca Mountain suggests that ravens are not a significant predator of small tortoises in this locale. Carcasses of small tortoises (less than 110 $\mathrm{mm}$ in length) collected during the study showed little evidence of raven predation, and 59 radiomarked hatchlings that were monitored on a regular basis were not preyed upon by ravens. Overall, no direct evidence of raven predation on tortoises was observed during this study. Small tortoises are probably encountered so infrequently by ravens that they are rarely exploited as a food source. This is likely due to the relatively low abundance of both desert tortoises and ravens in the Yucca Mountain area. 


\section{CONTENTS}

Page

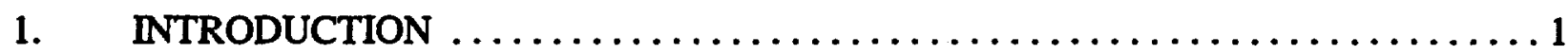

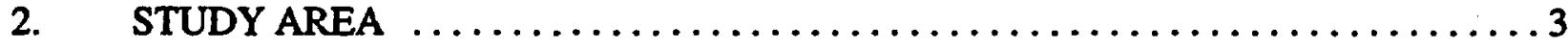

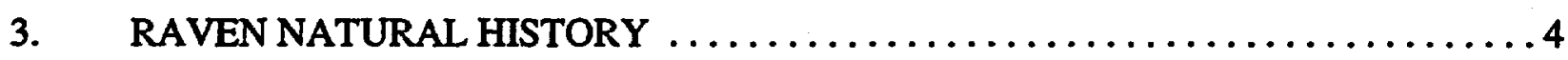

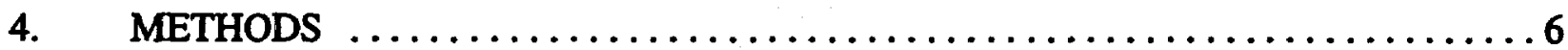

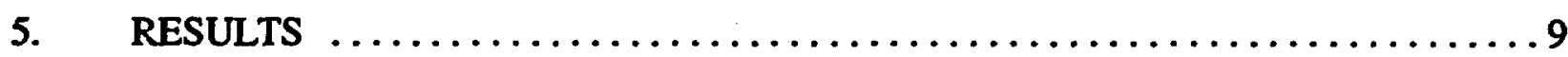

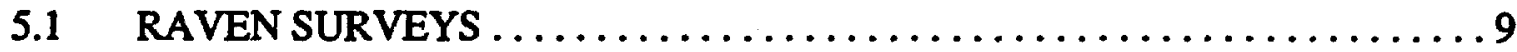

5.2 AVAILABIITY AND USE OF STRUCTURES BY RAVENS $\ldots \ldots \ldots \ldots, 9$

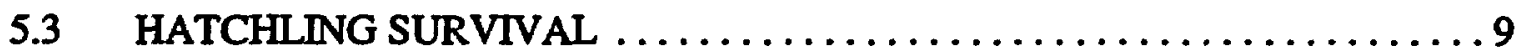

5.4 CARCASS COLLECTIONS $\ldots \ldots \ldots \ldots \ldots \ldots \ldots \ldots \ldots \ldots \ldots \ldots \ldots \ldots \ldots$

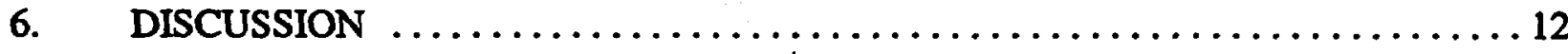

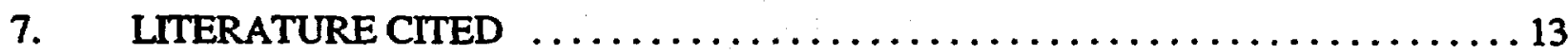




\section{TABLES}

Page

Table 1. Breeding bird survey results for ravens, $1966-1994 \ldots \ldots \ldots \ldots \ldots \ldots \ldots \ldots$

Table 2. Species observed and frequency of observation along treatment and control survey routes. . . . . . . . . . . . . . . . . . . . . . . .

Table 3. Mean number of ravens observed on treatment and control routes. ......... 10

Table 4. Counts of anthropogenic structures located along treatment and control survey routes. . . . . . . . . . . . . . . . . . . . . . . . 11 


\section{FIGURES}

Page

Figure 1. Location of treatment and control raven survey routes. $\ldots \ldots \ldots \ldots \ldots \ldots \ldots$

Figure 2. Number of ravens observed throughout the study expressed as the difference between treatment and control routes. ................. 11 


\section{INTRODUCTION}

In response to the Nuclear Waste Policy Act of 1982 (42 U.S.C. § 10101 et seq.) and the Nuclear Waste Policy Amendments Act of 1987 (42 U.S.C. § 10101-10270), the U.S. Department of Energy (DOE) developed and is implementing the Yucca Mountain Site Characterization Project. This project consists of a series of multi-disciplinary, scientific investigations designed to provide detailed information necessary to assess the suitability of Yucca Mountain, Nevada, for possible development of a geologic repository for high-level nuclear waste.

Surveys of the biological resources in the Yucca Mountain area determined that the desert tortoise (Gopherus agassizii) was the only vertebrate resident in the immediate vicinity of Yucca Mountain that was being considered for protection under the Endangered Species Act of 1973 (16 U.S.C. \& 1531). The Mojave population of the desert tortoise was emergency listed as endangered in August 1989 (U.S. Fish and Wildlife Service 1989), subsequently relisted as threatened in April 1990 (U.S. Fish and Wildlife Service 1990b), and a Recovery Plan for the species was developed (U.S. Fish and Wildlife Service 1994). Listing of the desert tortoise was prompted by declines in abundance that were attributed to habitat loss from increased land development, prolonged periods of drought, increased incidence of a lethal disease, and direct human disturbances such as vehicle impacts and poaching (Com 1994; U.S. Fish and Wildlife Service 1989, 1990a, 1990b, 1994). Another factor contributing to the listing of the tortoise was the assertion that increased avian predation on hatchling tortoises (primarily by common ravens, Corvus corax) may be affecting recruitment into populations in several areas of the Mojave Desert (Berry 1985; U.S. Bureau of Land Management 1990b; U.S. Fish and Wildlife Service 1990a, 1994). In fact, predation on hatchling tortoises by ravens has been perceived to be such a serious problem (cf. Doak et al. 1994) that a limited raven removal program (reviewed by Boarman 1993) was implemented by the U.S. Bureau of Land Management in several areas of the Mojave Desert during 1989, 1993, and 1994.

Ravens have been considered subsidized predators (Boarman 1993) because they use food, water, roosting sites, and nesting sites made available by increases in human facilities and activities (Knight and Kawashima 1993; Knight et al. 1993). By taking advantage of these resources, ravens may increase in abundance beyond the natural carrying capacity of an area. Many of the activities being conducted for the Yucca Mountain Site Characterization Project are the type that may result in increased raven abundance by increasing the raven resource base. For example, increased vehicle traffic in support of site characterization studies at Yucca Mountain could increase the incidence of animal road-kills, thereby increasing scavenging opportunities for ravens (e.g., Austin 1971; Conner and Adkisson 1976; Hooper 1977). Likewise, watering of roads to suppress dust and an increase in the number of open water sources could encourage ravens to stay in the area because of the provision of this otherwise scarce resource. Further, increased construction of roads, power poles, signs, buildings, and other structures could increase the availability of roosting and nest sites, also leading to increases in raven abundance (Engel and Young 1992; Engel et al. 1992; Knight and Kawashima 1993). For example, ravens have been found to be more numerous in areas with utility lines and highways than in areas without these structures (Knight and Kawashima 1993). Similarly, ravens were found to be uncommon in undeveloped and roadless interior areas of Joshua Tree National Monument (4.6 ravens per $100 \mathrm{~km}$ of transect; Camp et al. 1993a) when compared to much higher numbers observed along paved roads in the Mojave Desert (36.5 ravens per $100 \mathrm{~km}$ of transect; Knight and Kawashima 1993). 
Shortly after the Mojave population of the desert tortoise was listed as endangered in 1989, the DOE Yucca Mountain Site Characterization Office entered into formal consultation with the U.S. Fish and Wildlife Service, as required by Section 7 of the Endangered Species Act. Because additional human activities and support facilities at Yucca Mountain could result in an increase in raven abundance (e.g., Boarman 1993; U.S. Bureau of Land Management 1990b), and such increases could impact recruitment rates of young tortoises, a condition of the incidental take provision of the Biological Opinion issued to DOE (U.S. Fish and Wildlife Service 1990c) was to monitor the abundance of ravens.

The objective of this study was to determine if increases in activities and new construction associated with the Yucca Mountain Site Characterization Project resulted in increased raven abundance at Yucca Mountain when compared to a relatively undisturbed control area. Preliminary findings of this study (1991-1993) were reported by Holt and Mueller (1994). This report summarizes the final results of raven surveys conducted from 1991-1995. Also included is an evaluation of the impacts of ravens on the desert tortoise population based on both a study of tortoise hatchling survival (19921994), and inspection of tortoise carcasses collected in the Yucca Mountain area (1989-1995). 


\section{STUDY AREA}

Yucca Mountain is located in Nye County, Nevada, approximately $150 \mathrm{~km}$ northwest of Las Vegas. The Yucca Mountain site that is being evaluated by DOE is situated on land managed by three federal agencies: DOE, the U.S. Air Force, and the U.S. Bureau of Land Management. The areas managed by DOE and the Air Force have been reserved for use by government agencies in support of national security needs, and have been restricted from public access and grazing since the early 1950s. Bare Mountain, which is the control site used in this study, is located approximately $20 \mathrm{~km}$ west of Yucca Mountain on lands administered by the U.S. Bureau of Land Management.

The study area lies on the northern edge of the Mojave Desert along an ecotone between the Great Basin and Mojave deserts. The region is characterized by linear mountain ranges and broad valleys. The portion of Yucca Mountain being evaluated by DOE as a potential geologic repository is a ridge of volcanic origin oriented north to south, with a maximum elevation of about $1,510 \mathrm{~m}$. Bare Mountain is primarily limestone, with a maximum elevation of about $1,900 \mathrm{~m}$. Although Yucca and Bare Mountains are comprised of differing parent materials, they have similar plant communities (Niles et al. 1994). Two major floristic zones occur in the study area, a Mojave Desert zone and a transition zone between the Mojave and Great Basin deserts. Four vegetation associations commonly found in these zones cover most of the study area (Beatley 1976; O'Farrell and Collins 1984; CRWMS M\&O 1996a), and are dominated by the shrubs Larrea tridentata, Ambrosia dumosa, Grayia spinosa, Lycium andersonii, Coleogyne ramosissima, and Ephedra nevadensis.

The study area experiences limited and erratic precipitation, low relative humidity, and large daily temperature fluctuations. Average annual precipitation from 1960-1995 at weather station 4JA, approximately $13 \mathrm{~km}$ southeast of Yucca Mountain, was $13.9 \mathrm{~cm}$ (DOE Nevada Operations Office, unpublished data). Average annual precipitation from 1972-1995 at weather station Beatty-8N, approximately $15 \mathrm{~km}$ north of Bare Mountain, was $15.4 \mathrm{~cm}$ (NOAA 1996). The average daily minimum and maximum temperatures at Yucca Mountain during December were $2^{\circ}$ and $10^{\circ} \mathrm{C}$, respectively (recorded at Yucca Mountain from 1986-1995, DOE Yucca Mountain Site Characterization Office, unpublished data). Average minimum and maximum temperatures in December at Beatty-8N during $1972-1995$ were $-2^{\circ}$ and $13^{\circ} \mathrm{C}$, respectively (NOAA 1996). The average daily minimum and maximum temperatures during July at Yucca Mountain were $22^{\circ}$ and $34^{\circ} \mathrm{C}$, respectively (DOE unpublished data), while the average daily minimum and maximum temperatures during the same month at Beatty-8N during $1972-1995$ were $17.4^{\circ}$ and $29.2^{\circ} \mathrm{C}$, respectively (NOAA 1996). 


\section{RAVEN NATURAL HISTORY}

The common raven is a holarctic species found in North America from Alaska through northern Canada, and south through the western United States and Mexico (Knight and Call 1980). Ravens are generally nonmigratory throughout their range but there is some evidence of a partial migration from extreme northern habitats (Bent 1964).

Ravens are omnivorous and obtain food from a wide variety of sources. They are known to kill many types of animals for food, including invertebrates, amphibians, reptiles, birds, and small mammals, and commonly eat carrion and food stolen from other animals (Bent 1964; Engel and Young 1989; Knight and Call 1980; Goodwin 1986). Raven pellets $(n=226)$ collected from nest sites in the Mojave Desert contained inorganic material $(98 \%$; i.e., percentage of pellets containing specific food type), vertebrates ( $96 \%$ ), vegetation (92\%), invertebrates (86\%), and garbage (22\%) (Camp et al. 1993b). Analysis of pellets $(n=574)$ collected from roost sites in Idaho showed that cereal grains from agricultural crops ( $97 \%$ contained grains, representing $74 \%$ of total pellet weight) were much more important diet items in that area compared to animal components (Engel and Young 1989).

Ravens can be observed at any time during the day, yet the feeding patterns of five radiomarked ravens in the Mojave Desert, May-June 1991, were bimodal, with peaks of activity from 0500-0900 and 1200-1800 hours (Sherman and Knight 1992).

Results of the Breeding Bird Survey from 1966-1994 (summarized by U.S. Fish and Wildlife Service, see also Robbins et al. 1986; Sauer et al. 1996), indicated that raven populations increased in the western region of the United States, which includes California, Oregon, Washington, Idaho, and Nevada (Table 1). When analyzed by state, however, only Califormia and Washington showed statistically significant increases. Nevada showed a slight, but not statistically significant decline in abundance of ravens. When analyzed separately, the Mojave Desert showed a significant $7.5 \%$ per year increase in abundance. This translates to a $658 \%$ increase in abundance of ravens in the Mojave Desert between 1966 and 1994. This value of $658 \%$ may not be representative of the entire Mojave Desert since the Breeding Bird Surveys are conducted only along roads, where ravens are known to be more abundant (e.g., Knight and Kawashima 1993).

The fact that ravens occasionally eat desert tortoises has been known for over 60 years (Miller 1932). Campbell (1983) reported that 136 of 140 tortoise carcasses collected along a fence at the Desert Tortoise Natural Area, Kern County, California, were probably killed, eaten, and/or collected by birds (most likely ravens). Nineteen of 57 tortoise carcasses collected on or near the Sheep Mountain Permanent Study Plot, Clark County, Nevada, were attributed to raven predation (Esque and Duncan 1985). Evidence of raven predation on tortoises was also found at three nests and one feeding site during raven nesting surveys conducted in the eastern Mojave Desert of southern California (Farrell 1989). During one of those surveys, a raven was observed feeding on a freshly killed tortoise. Tortoise remains were found in raven pellets collected from 2 of 39 active raven nests in the eastern Mojave Desert (Camp et al. 1993b). Carcasses of small tortoises that could have been killed by ravens were collected from 13 of 27 tortoise study sites in California (Berry 1985). 
Table 1. Breeding bird survey results for ravens, 1966-1994. From Sauer et al. 1996.

\begin{tabular}{lccccc}
\hline Sampling Unit & Trend $^{\mathrm{a}}$ & $P^{\mathrm{b}}$ & $N^{\mathrm{c}}$ & $95 \% \mathrm{Cl}^{\mathrm{d}}$ & R.A. $^{\mathrm{c}}$ \\
\hline California & 5.4 & $* * *$ & 143 & $3.8-7.1$ & 6.88 \\
Idaho & 11.1 & & 42 & $-17.2-39.4$ & 3.69 \\
Nevada & -3.3 & & 24 & $-13.9-7.4$ & 6.23 \\
Oregon & -0.6 & & 86 & $-4.4-3.3$ & 7.49 \\
Washington & 4.7 & $* * *$ & 59 & $1.1-8.2$ & 3.49 \\
Region One & 3.0 & $* * *$ & 354 & $0.7-5.3$ & 5.91 \\
Mojave Desert & 7.5 & $* *$ & 19 & $0.4-14.6$ & 9.28 \\
\hline
\end{tabular}

- Estimated population trend as percent change per year.

${ }^{b}$ Probability that the trend differs from zero. ${ }^{* * *}: P<0.01$; **:P $<0.05$; ${ }^{*}: P<0.1$; no asterisk indicates not significant at $P=0.1$.

c Number of survey routes used in the estimate of trends.

¿95\% confidence interval of the trend estimate.

' Weighted regional abundance expressed in average number of birds per survey route.

'Administrative region including California, Idaho, Nevada, Oregon, and Washington.

Berry (1985) also reported tortoise carcasses at three of 19 raven nests surveyed, and remains of 28 juvenile tortoises were found on a low knoll a few hundred meters from one of the nests.

Young tortoises naturally have a high rate of mortality (U.S. Fish and Wildlife Service 1994). Because most of the cases presented here represent indirect or anecdotal information, most of these accounts could represent scavenging by ravens rather than predation. Actual observations of ravens killing tortoises have been reported (U.S. Bureau of Land Management 1990b:20), yet there is no solid evidence for the assertion (U.S. Bureau of Land Management 1990a, 1990b) that ravens account for $15-50 \%$ of young tortoise mortality on a regional scale in California. It is clear that ravens prey upon young tortoises to some extent. However, a relationship between raven predation on young tortoises and declines in desert tortoise abundance has not been demonstrated, and whether ravens have caused declines in tortoise abundance needs to be examined more rigorously (U.S. Fish and Wildlife Service 1990a). 


\section{METHODS}

Ravens were counted for this study using roadside count surveys. One example of this technique is the Breeding Bird Survey (Robbins et al. 1986; Sauer et al. 1996), used annually by the U.S. Fish and Wildlife Service and the Canadian Wildlife Service to estimate population trends of North American birds. Roadside count surveys were well-suited for determining the abundance of ravens in the Yucca Mountain area because ravens occur in relatively low densities, and large areas had to be surveyed to ensure an adequate sample size. Roadside count surveys have also been used to estimate low-abundance raptor (bird of prey) population trends (Fuller and Mosher 1987; McCrary et al. 1985; Hubbard et al. 1988). Additionally, ravens are wide-ranging and highly visible animals and frequently use or are associated with structures of anthropogenic origin (e.g., roads, buildings, utility poles, landfills, sewage ponds). Also, ravens are more frequently observed in areas with roads than in areas without roads (Knight and Kawashima 1993).

Surveys for ravens were conducted simultaneously along a treatment route in the immediate Yucca Mountain area, and a control route in the Bare Mountain area west of Yucca Mountain (Figure 1). The treatment route was selected based on its proximity to proposed and on-going site characterization activities and support facilities. The control area was selected because no Yucca Mountain site characterization activities, and very few other anthropogenic activities, were taking place there. In addition, the length and type of roads, vegetation types, elevation, topography, and climate were similar to the treatment route. Each route was $40 \mathrm{~km}$ long and included 50 stops spaced $0.8 \mathrm{~km}$ apart. Surveys began four hours after sunrise. At each stop, the observer exited the vehicle and looked for ravens for one minute. Because other avian species have also been implicated in tortoise predation (Berry 1985), sightings of raptor species also were recorded. Ravens that were flying or perched on structures were more likely to be visible than birds on the ground; therefore, association with anthropogenic structures was noted. Binoculars were not used to search for ravens, but only to positively identify birds when sighted.

Surveys were conducted every other month on five randomly selected days during August 1991 through August 1994, and on three randomly selected days during October 1994 through August 1995. The raven population was monitored year-round rather than only during the tortoise activity season because site characterization activities may increase the area's carrying capacity for ravens by providing food sources (e.g., garbage and road-killed animals) during periods of limited food availability, such as winter and mid-summer.

To assess qualitative differences in the number and type of anthropogenic structures along the treatment and control raven survey routes, the number and type of structures visible within $400 \mathrm{~m}$ of each stop were counted during a separate survey in December 1993. Three categories of structures known to be used by ravens were used: fence posts (wood, metal, or concrete; less than $1.5 \mathrm{~m}$ in height), other vertical structures (e.g., wooden telephone or power poles, transmission or communications towers), and buildings of any type or size. 


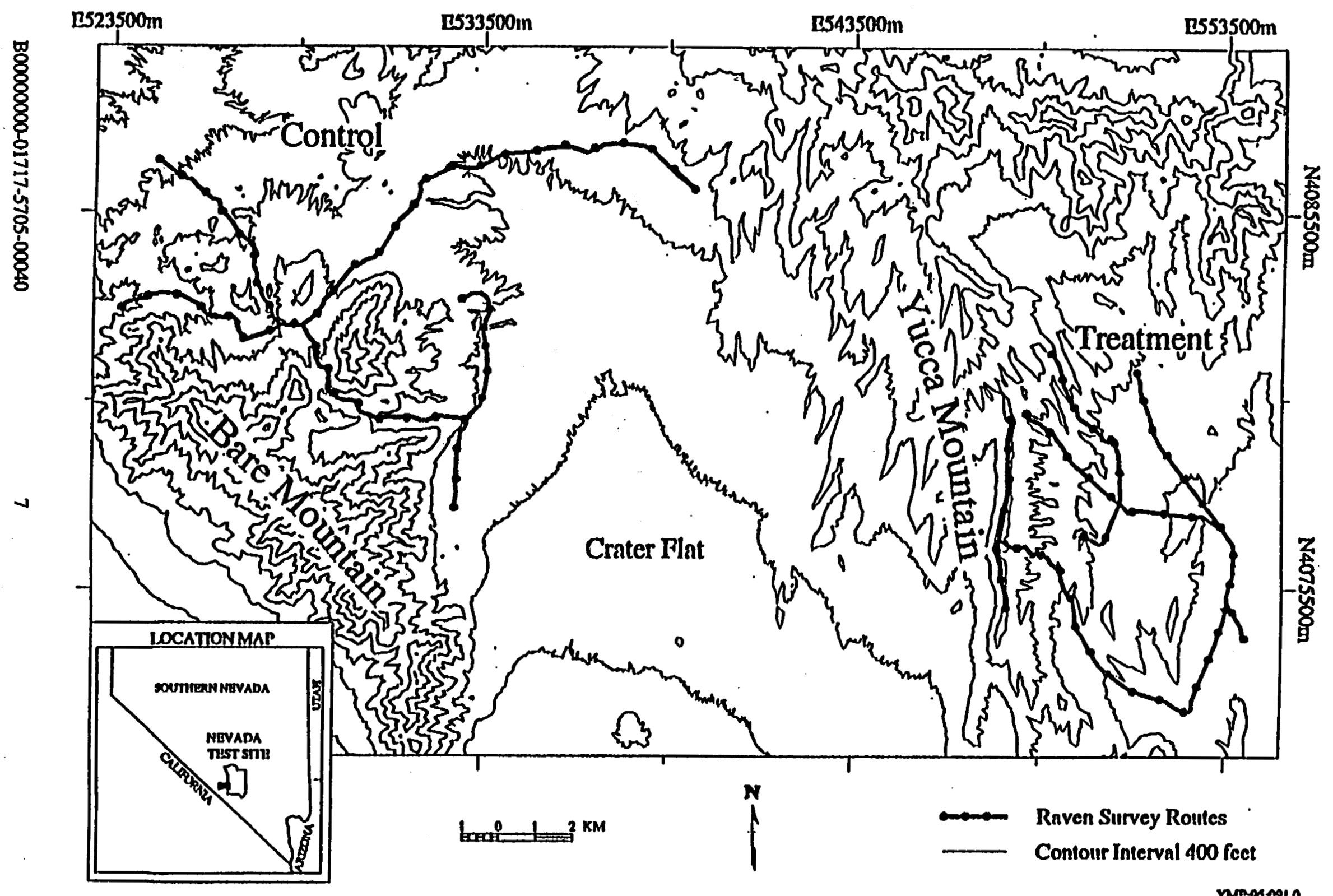

Figure 1. Location of treatment and control raven survey routes. Each route contains 50 stops, spaced $0.8 \mathrm{~km}$ apart. Three stops on the treatment route are not shown. They are located near the Field Operations Center which is southeast of the map. 
Abundance data were analyzed similar to the BACI (Before-After/Control-Impact) design described by Stewart-Oaten et al. (1986). The BACI design requires taking samples, replicated in time, Before and After a disturbance has occurred at a Control site and an Impacted (i.e., treatment) site. This design is ideal for monitoring impacts from disturbances that are manifested in a short period of time, such as the start-up of a power plant. However, there was no clearly defined start-up time for Yucca Mountain Site Characterization Project activities. Comparatively small-scale activities associated with initial site evaluation began in the early 1980s. A major increase in activities in the Yucca Mountain area occurred when ground clearing for the Exploratory Studies Facility began on November 28, 1992. This marked the beginning of a substantial increase in human activity and construction activities at Yucca Mountain. Therefore, this date was used as the demarcation between predisturbance (Before) and the period of time when construction activities were conducted at much higher levels (After). For example, approximately $80 \%$ of the 121 ha of habitat disturbed by groundclearing activities during 1991-1995 occurred after November 1992. Traffic volume in the Yucca Mountain area increased each year from 1991-1994, most likely providing an increased availability of road-killed animals for ravens to scavenge. The number of people working at Yucca Mountain more than doubled in early 1993 and increased gradually from then until September 1995 (DOE 1995). These increases in traffic and the number of individuals working in the area are likely indicative of increased opportunities for ravens to obtain food from garbage and road-killed animals, water from the watering of roads, and roosting sites provided by an increasing number of power lines and buildings necessary to support the increase in activities in the Yucca Mountain area.

The dependent variable used for statistical analysis of population trends was the difference between the number of ravens observed on treatment and control routes for each survey. To determine if site characterization activities had a significant effect on the abundance of ravens in the Yucca Mountain area, these differences were compared for the before- and after-disturbance periods using a $t$-test (Stewart-Oaten et al. 1986). The results of this test are analogous to using a two-way analysis of variance with interaction on the raw survey values (Underwood 1994). The null hypothesis that the relative number of ravens observed on treatment and control routes were equal (i.e., differences between treatment and control were equal to zero) across the entire study was tested using a paired $t$-test. Statistical procedures were carried out using SYSTAT ${ }^{\circ}$ (1992), and $\alpha=0.1$ was used as the standard to determine whether departures from the null hypothesis were significant. An $\alpha$ value of 0.1 was used to better balance the probabilities of Type I and Type II errors (Skalski and Robson 1992:21-22). Power calculations (Cohen 1988) and modeling of sample size sufficiency were conducted using NCSS-PASS ${ }^{\circledR}$ (Hintze 1993).

To evaluate potential impacts of raven abundance on desert tortoises in the area, all carcasses of tortoises collected in the Yucca Mountain area during 1989-1995 were examined for evidence of avian predation. In addition, information on the survival and sources of mortality of radiomarked hatchling tortoises monitored for the Desert Tortoise Monitoring Program during 1992-1994 was evaluated for evidence of raven impacts. 


\section{RESULTS}

\subsection{RAVEN SURVEYS}

A total of 226 raven surveys $(9,040 \mathrm{~km})$, equally split between treatment and control routes, were conducted between August 1,1991 and August 29, 1995. Eighty surveys $(3,200 \mathrm{~km})$ were conducted before the increase in disturbance at Yucca Mountain, and $146(5,840 \mathrm{~km})$ were conducted after the start of disturbances. A total of 685 ravens were observed during all the surveys combined ( $\bar{x}=3.0$ ravens per survey, or 7.5 ravens per $100 \mathrm{~km}$ surveyed). An additional 242 observations of 12 raptor species were recorded (Table 2), at a much lower frequency compared to ravens. The most common raptor observed was the red-tailed hawk (Buteo jamaicensis), which was tallied 105 times. The number of ravens observed on survey routes was variable (Table 3 ), making the difference between treatment and control also variable (Figure 2). The mean number of ravens increased over time on both the treatment and control survey routes (Table 3). Before increased disturbance in November 1992, the average difference in the number of ravens observed between treatment and control surveys was 1.1 per survey. After the increase in disturbances, the average difference was 1.0 per survey. These values were not significantly different $(t=0.183, \mathrm{df}=111, P=0.855)$, indicating that site characterization activities did not influence the number of ravens observed on the survey routes. Although no significant effects of site characterization were detected, an average difference between treatment and control surveys of one raven could have been detected with $45 \%$ power, and a difference of two ravens with approximately $90 \%$ power.

An average of 3.5 ravens per survey was recorded on the treatment route $(n=400)$ throughout the study, whereas an average of 2.5 ravens per survey was recorded on the control route $(n=285)$. The overall difference in abundance of ravens between treatment and control routes was significantly different from zero (paired $t$-test, $t=3.071, \mathrm{df}=112, P=0.003$ ). Red-tailed hawks were also observed more frequently on the treatment route ( $n=60$, or $0.5 /$ survey) than on the control route ( $n$ $=45$, or 0.4 /survey).

\subsection{AVAILABILITY AND USE OF STRUCTURES BY RAVENS}

When counted in December 1993, there were more anthropogenic structures located along the treatment route than on the control (Table 4). In particular, the proportion of fence posts and buildings counted along survey routes was higher on the treatment route than on the control $\left(\chi^{2}=\right.$ $247.67, \mathrm{df}=2, P<0.001$ ). This was due primarily to the fencing of many disturbed areas, and the comparatively large number of support buildings throughout the Yucca Mountain area. When quantified during surveys in 1993-1995, 22.5\% of raven observations on the treatment route were associated with anthropogenic structures. Only $2.7 \%$ of observations on the control route were associated with structures.

\subsection{HATCHLING SURVIVAL}

During the Desert Tortoise Monitoring Program (1991-1995) over 100 small tortoises $<110 \mathrm{~mm}$ mid-carapace length) were radiomarked and monitored for varying lengths of time. Included in this group were 59 hatchlings (all less than $50 \mathrm{~mm}$ in length) that were radiomarked during 1992, 1993 
Table 2. Species observed and frequency of observation along treatment and control survey routes.

\begin{tabular}{lrcc}
\hline & \multicolumn{3}{c}{ Number Observed } \\
\cline { 2 - 4 } Species & Treatment & Control & Total \\
\hline Common Raven (Corvus corax) & 400 & 285 & 685 \\
Red-tailed Hawk (Buteo jamaicensis) & 60 & 45 & 105 \\
Golden Eagle (Aquila chrysaetos) & 8 & 20 & 28 \\
Turkey Vulture (Cathartes aura) & 15 & 9 & 24 \\
Northern Harrier (Circus cyaneus) & 4 & 15 & 19 \\
American Kestrel (Falco sparverius) & 16 & 3 & 19 \\
Prairie Falcon (Falco mexicanus) & 1 & 5 & 6 \\
Cooper's Hawk (Accipiter cooperii) & 0 & 4 & 4 \\
Swainson's Hawk (Buteo swainsoni) & 4 & 0 & 4 \\
Sharp-shinned Hawk (Accipiter striatus) & 0 & 3 & 3 \\
Osprey (Pandion haliaetus) & 1 & 1 & 2 \\
Ferruginous Hawk (Buteo regalis) & 1 & 0 & 1 \\
Rough-legged Hawk (Buteo lagopus) & 1 & 0 & 1 \\
Unknown raptor & 14 & 12 & 26 \\
\hline
\end{tabular}

Table 3. Mean number of ravens observed on treatment and control routes, before and after the increase in activities at Yucca Mountain.

\begin{tabular}{lllll}
\hline Time Period & Route & $\bar{x}$ & $n^{\mathrm{a}}$ & SE $^{\mathrm{b}}$ \\
\hline Before & Treatment & 2.9 & 40 & 0.35 \\
& Control & 1.8 & 40 & 0.34 \\
\multirow{2}{*}{ After } & Treatment & 3.9 & 73 & 0.38 \\
& Control & 2.9 & 73 & 0.40 \\
\hline
\end{tabular}

- Number of surveys.

- Standard error.

and 1994 when they emerged from nests. The overall survival rate of hatchlings was $60 \%$ (35 of 59) from the time of emergence from nests (approximately mid-August through September) to the onset of hibernation (October through early November). Of the 24 hatchlings that died, no avian predation was documented (Goodwin et al. 1995). 


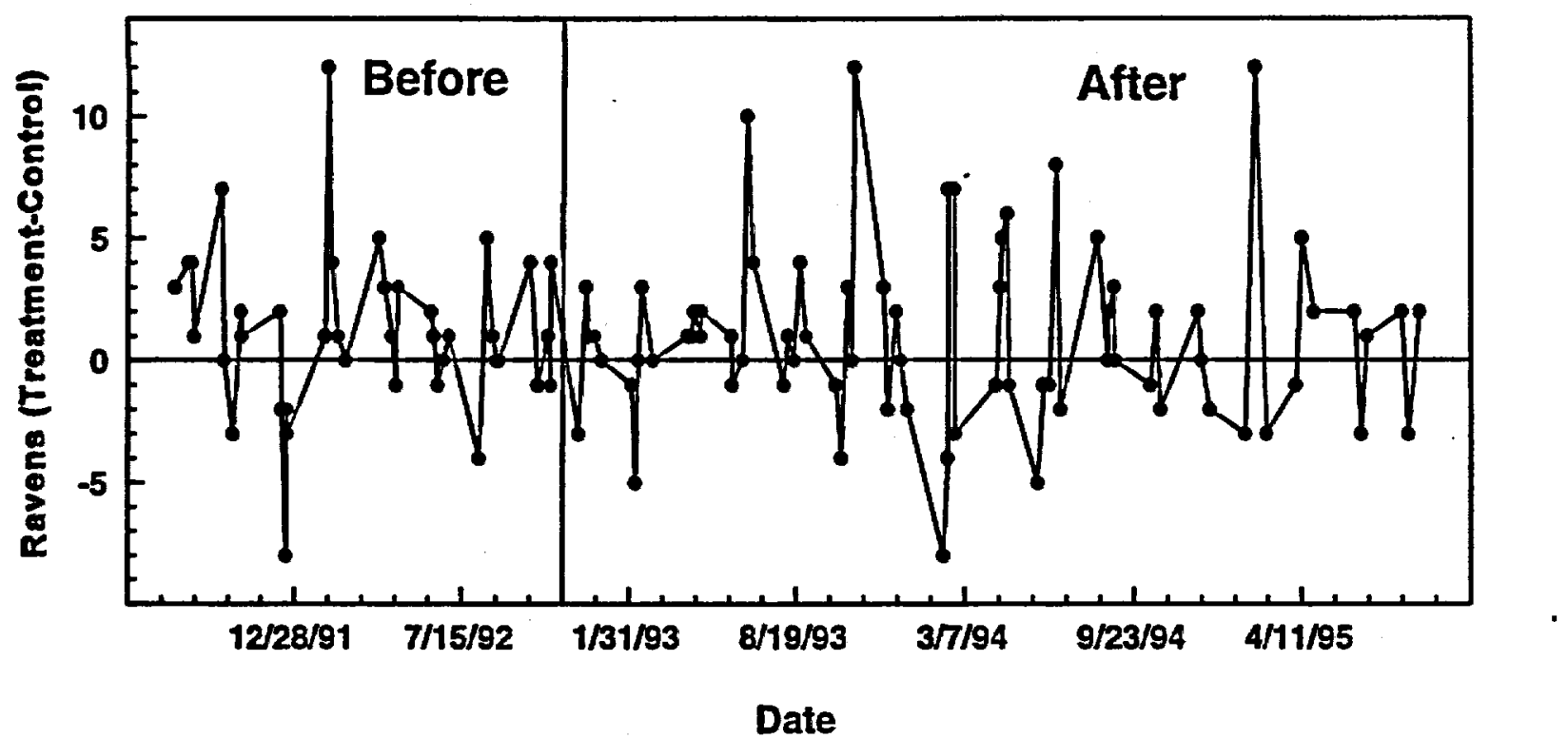

Figure 2. Number of ravens observed throughout the study expressed as the difference between treatment and control routes.

Table 4. Counts of anthropogenic structures located along treatment and control survey routes.

\begin{tabular}{lcccc}
\hline Survey Route & Fence Posts & $\begin{array}{c}\text { Other Vertical } \\
\text { Structures }\end{array}$ & Buildings & Totals \\
\hline Treatment & 822 & 321 & 42 & 1185 \\
Control & 116 & 290 & 3 & 409 \\
\hline
\end{tabular}

\subsection{CARCASS COLleCtions}

Young tortoises are susceptible to raven predation until their protective carapace has fully hardened, which occurs by the time they are approximately $110 \mathrm{~mm}$ in length. For example, all of the 150 tortoises reported to have been killed by ravens in one California study were less than $103 \mathrm{~mm}$ in length (Berry 1985). Between July 1989 and July 1995, 53 tortoise carcasses less than $110 \mathrm{~mm}$ in length were collected in the Yucca Mountain area. None of the 24 monitored hatchlings that died (see Section 5.3) were included in this total. The ability to determine the cause of death varied, because some were represented by only a small portion of a carapace or plastron and the cause of death was impossible to determine, whereas others were fresh road-kills and the cause of death was clearly evident. Notes taken at the time of collection indicate that 7 of these 53 carcasses showed evidence of being preyed upon or scavenged by ravens or raptors, including 2 with holes in the plastron. These types of holes have been used as evidence of raven predation in the past (e.g., Berry 1985). However, direct evidence of predation by ravens on young tortoises, such as ravens feeding on a freshly killed animal or carrying a young tortoise, was never observed during this study. 


\section{DISCUSSION}

Ravens were more abundant in the Yucca Mountain treatment area throughout the study (about 3.5 ravens observed per survey) compared to the control survey route at Bare Mountain (about 2.5 ravens observed per survey). Although the number of ravens observed per survey increased over time, the magnitude of differences between treatment and control routes did not change, indicating that increases observed on the treatment route were unrelated to site characterization activities. These results agree with earlier analyses of the data and preliminary conclusions made prior to the end of the study (Holt and Mueller 1994). In addition, ravens on the treatment route were more frequently observed in association with anthropogenic structures compared to control observations. This is a reflection of the greater availability of structures along the treatment route.

Although differences in methodology preclude quantitative comparisons, increases in raven abundance over time on both the treatment and control routes are consistent with the region-wide increase in abundance reported by the Breeding Bird Survey (Sauer et al. 1996). The number of ravens observed on the treatment route ( 3.5 ravens per $40 \mathrm{~km}$ surveyed or 8.8 ravens per $100 \mathrm{~km}$ surveyed) was more similar to the number of ravens observed in the roadless areas of Joshua Tree National Monument (4.6 ravens per $100 \mathrm{~km}$ of transect) (Camp et al. 1993a) than to surveys conducted along paved roads in the Mojave Desert (36.5 ravens per $100 \mathrm{~km}$ of transect) (Knight and Kawashima 1993). Over the entire Mojave Desert, Breeding Bird Survey results showed an average of 9.3 ravens sighted per survey (23.2 per $100 \mathrm{~km}$ ) during 1966-1994 (Sauer et al. 1996). Again, methodology is slightly different since Breeding Bird Surveys are conducted only once per year, consist of 50 three-minute stops spaced $0.8 \mathrm{~km}$ apart, and only count birds sighted within 400 meters of a stop. Despite the differences in methodology, raven abundance in the Yucca Mountain area probably is lower than in most other areas surveyed in the Mojave Desert as reported in the Breeding Bird Survey.

Although nest surveys were not conducted in the Bare Mountain area, ravens commonly nest on the Nevada Test Site (Hayward et al. 1963, Greger 1994) and in the vicinity of Yucca Mountain. Three nest sites in the Yucca Mountain area that were investigated during the study period showed no evidence of recent or past predation on desert tortoises (Holt and Mueller 1994). In addition, little evidence of raven predation was evident from carcasses collected over the course of six years, and there was no evidence of predation on radiomarked hatchling tortoises that were closely monitored.

Evidence from the Desert Tortoise Monitoring Program at Yucca Mountain suggests that ravens are not a significant predator of small tortoises in this locale. Small tortoises are probably encountered so infrequently by ravens that they are rarely exploited as a food source. This is likely due to the relatively low abundance of both desert tortoises (see CRWMS M\&O 1996b) and ravens in the Yucca Mountain area. 


\section{LITERATURE CITED}

Austin, G.T. 1971. "Roadside Distribution of the Common Raven in the Mojave Desert." Califomia Birds 2:98.

Beatley, J.C. 1976. Vascular Plants of the Nevada Test Site and Central-Southern Nevada: Ecologic and Geographic Distributions. TID-26881. Springfield, Virginia: National Technical Information Center, Office of Technical Information, Energy Research and Development Administration.

Bent, A.C. 1964. Life Histories of North American Jays, Crows, and Titmice. Vol. I. New York, New York: Dover Publishing, Inc.

Berry, K.H. 1985. Avian Predation on the Desert Tortoise (Gopherus agassizii) in California. Report to Southern California Edison Co., Riverside, California: U.S. Bureau of Land Management.

Boarman, W.I. 1993. "When a Native Predator Becomes a Pest: A Case Study." In Majumdar, S.K.; Miller, S.W.; Baker, D.E.; Brown, E.K.; Pratt, J.R.; and Schmalz, R.F. (Eds.) Conservation and Resource Management. Pennsylvania: The Pennsylvania Academy of Science.

Camp, R.J.; Knight, R.L.; and Freilich, J. 1993a. "Common Raven Populations in Joshua Tree National Monument, California." Western Birds 24:198-199.

Camp, R.J.; Knight, R.L.; Knight, H.A.L.; Sherman, M.W.; and Kawashima, J.Y. 1993b. "Food Habits of Nesting Common Ravens in the Eastern Mojave Desert." Southwestern Naturalist 38:163-165.

Campbell, T. 1983. "Some Natural History Observations of Desert Tortoises and Other Species on and near the Desert Tortoise Natural Area, Kern County, California." Proceedings of the Desert Tortoise Council Symposium 1983:80-88.

Cohen, J. 1988. Statistical Power Analysis for the Behavioral Sciences. Hillsdale, New Jersey: Lawrence Erlbaum Associates.

Conner, R.N. and Adkisson, C.S. 1976. "Concentration of Foraging Common Ravens along the Trans-Canada Highway." Canadian Field-Naturalist 90:496-497.

Com, P.S. 1994. "Recent Trends of Desert Tortoise Populations in the Mojave Desert." In R.B. Bury and D.J. Germano (Eds.), Biology of North American Tortoises (pp. 89-93). U.S. National Biological Survey, Fish and Wildlife Research Report 13. Washington, DC: U.S. Fish and Wildlife Service. 
CRWMS M\&O [Civilian Radioactive Waste Management System Management and Operating Contractor] 1996a. Hessing, M.B.; Lyon, G.E.; Sharp, G.T.; Ostler, W.K.; Green, R.A.; and Angerer, J.P. The Vegetation of Yucca Mountain: Description and Ecology. B00000000-01717-575-00031. Las Vegas, Nevada: U.S. Department of Energy.

CRWMS M\&O. 1996b. Lederle, P.E.; Rautenstrauch, K.R.; Rakestraw, D.L.; and Mueller, J.M. The Distribution and Relative Abundance of Desert Tortoises at Yucca Mountain. B0000000001717-5705-00033. Las Vegas, Nevada: U.S. Department of Energy.

Doak, D.; Kareiva, P; and Klepetka, B. 1994. "Modeling Population Viability for the Desert Tortoises in the Western Mojave Desert." Ecological Applications 4:446-460.

DOE [U.S. Department of Energy] 1995. Socioeconomic Monitoring Program Quarterly Employment Data Report: July 1995 through September 1995. Washington, D.C.: Office of Civilian Radioactive Waste Management System.

Endangered Species Act of 1973. 16 U.S.C. $\$ 1531$.

Engel, K.A. and Young, L.S. 1989. "Spatial and Temporal Patterns in the Diet of Common Ravens in Southwestern Idaho." Condor 91:372-378.

Engel, K.A., and Young, L.S. 1992. "Movements and Habitat Use by Common Ravens from Roost Sites in Southwestern Idaho." Journal of Wildlife Management 56:96-602.

Engel, K.A.; Young, L.S.; Steenhof, K.; Roppe, J.A.; and Kochert, M.N. 1992. "Communal Roosting of Common Ravens in Southwestern Idaho. Wilson Bulletin 104:105-121.

Esque, T.C. and Duncan, R.B. 1985. "A Population Study of the Desert Tortoise (Gopherus agassizii) at the Sheep Mountain Study Plot in Nevada." Proceedings of the Desert Tortoise Council Symposium 1985:47-67.

Farrell, J.P. 1989. "Natural History Observations of Raven Behavior and Predation on Desert Tortoises." Proceedings of the Desert Tortoise Council Symposium 1989:168 (abstract only).

Fuller, M.R. and Mosher, J.A. 1987. "Raptor Survey Techniques." In Pendleton, B.A.; Millsap, B.A.; Cline, K.W.; and Bird, D.M. (Eds.) Raptor Management Techniques Manual. Washington, D.C.: National Wildlife Federation.

Greger, P. 1994. "Status of Large Mammals and Birds on the Nevada Test Site in 1993." In Hunter, R.B. (compiler), Status of the Flora and Fauna on the Nevada Test Site, 1993. DOE/NV/11432-162. Las Vegas, Nevada: U.S. Department of Energy.

Goodwin, D. 1986. Crows of the World. Second ed. Seattle, Washington: University of Washington Press. 
Goodwin, R.G.; Mueller, J.M.; and Rautenstrauch, K.R. 1995. "Survival, Movements, and Burrow Use of Hatchling Desert Tortoises at Yucca Mountain, Nevada." Proceedings of the Desert Tortoise Council Symposium 1995:70 (abstract only).

Hayward, C.L.; Killpack, M.L.; and Richards, G.L. 1963. "Birds of the Nevada Test Site." Brigham Young University Science Bulletin Biological Series 3:2289-2316.

Hintze, J.L. 1993. Number Cruncher Statistical System, Power Analysis and Sample Size. Kaysville, Utah: J.L. Hintze.

Holt, E.A. and Mueller, J.M. 1994. "Monitoring Raven Abundance at Yucca Mountain." Proceedings of the Desert Tortoise Council Symposium 1994:125-129.

Hooper, R.G. 1977. "Nesting Habitat of Common Ravens in Virginia." Wilson Bulletin 89:233-242.

Hubbard, J.P.; Shipman, J.W.; and Williams, S.O. 1988. "An Analysis of Vehicular Counts of Roadside Raptors in New Mexico, 1974-1985." National Wildlife Federation Scientific Technical Series 11:204-209.

Knight, R.L. and M.W. Call. 1980. The Common Raven. U.S. Bureau of Land Management Technical Note \#344.

Knight, R.L. and J.Y. Kawashima. 1993. "Responses of Raven and Red-tail Hawk Populations to Linear Right-of-ways." Journal of Wildlife Management 57:266-271.

Knight, R.L.; Knight, H.A.L.; and Camp. R.J. 1993. "Raven Populations and Land-use Patterns in the Mojave Desert, California." Wildlife Society Bulletin 21:469-471.

McCrary, M.D.; McKernan, R.L.; Wagner, W.D.; and Landry, R.E. 1985. "Roadside Raptor Census in the San Jacinto Valley of Southern California, USA." Western Birds 16:123-130.

Miller, L. 1932. "Notes on the Desert Tortoise (Testudo agassizii)." Transactions of the San Diego Society of Natural History 7:187-208.

Niles, W.E.; Leary, P.J.; Holland, J.S.; and Landau, F.H. 1994. A Floristic Survey of Yucca Mountain and Vicinity, Nye County, Nevada. U.S. Department of Energy report, Nevada Operations Office, Contract No. DOE/NV DE-FC08-90NV10872. Las Vegas, Nevada: U.S. Department of Energy.

NOAA [National Oceanic and Atmospheric Administration]. 1996. Temperature and Precipitation Data for Beatty-8N, Nevada (1972-1995). Western Region Climate Center, Reno, Nevada.

Nuclear Waste Policy Act of 1982. 42 U.S.C. $\S 10101$ et seq.

Nuclear Waste Policy Amendments Act of 1987. 42 U.S.C. $\S 10101-10270$. 
OFarrell, T.P. and Collins, E. 1984. 1983 Biotic Survey of Yucca Mountain, Nevada Test Site, Nye County, Nevada. U.S. Department of Energy report EGG 10282-2031. Springfield, Virginia.

Robbins, C.S.; Bystrak, D.; and Geissler, P.H. 1986. The Breeding Bird Survey: Its First Fifteen Years, 1965-1979. U.S. Fish and Wildlife Service Resource Publication 157. Washington, D.C.: U.S. Fish and Wildlife Service.

Sauer, J.R.; Schwarz, S.; Peterjohn, B.G.; and Hines, J.E. 1996. The North American Breeding Bird Survey Home Page. Version 94.3. Laurel, Maryland: Patuxent Wildlife Research Center.

Sherman, M.W. and Knight, R.L. 1992. "Time-activity Budgets of Nesting Common Ravens in the East Mojave Desert." Proceedings of the Desert Tortoise Council Symposium 1992:125 (abstract only).

Skalski, J.R. and Robson, D.S. 1992. Techniques for Wildlife Investigations. Design and Analysis of Capture Data. New York: Academic Press.

Stewart-Oaten, A.; Murdoch, W.W.; and Parker, K.R. 1986. "Environmental Impact Assessment: "Pseudoreplication" in Time?" Ecology 67:929-940.

SYSTAT. 1992. SYSTAT for Windows: Statistics, Version 5 Edition. SYSTAT, Inc.: Evanston, Ilinois.

Underwood, A.J. 1994. “On Beyond BACI: Sampling Designs That Might Reliably Detect Environmental Disturbances." Ecological Applications 4:3-15.

U.S. Bureau of Land Management. 1990a. Draft Environmental Impact Statement for the Management of the Common Raven in the California Desert Conservation Area. Riverside, California: U.S. Bureau of Land Management.

U.S. Bureau of Land Management. 1990b. Draft Raven Management Plan for the California Desert Conservation Area. Riverside, California: U.S. Bureau of Land Management.

U.S. Fish and Wildlife Service. 1989. "Endangered and Threatened Wildlife and Plants; Desert Tortoise." Federal Register 54(197):42270-42278.

U.S. Fish and Wildlife Service. 1990a. Assessment of Biological Information for Listing the Desert Tortoise as an Endangered Species in the Mojave Desert: Predecision Document. Portland Oregon: National Ecology Research Center, Region One.

U.S. Fish and Wildlife Service. 1990b. "Endangered and Threatened Wildlife and Plants; Determination of Threatened Status for the Mojave Population of the Desert Tortoise." Federal Register 55(63):12178-12191. 
U.S. Fish and Wildlife Service. 1990c. Biological opinion on effects of activities associated with the proposed Site Characterization Plan for the Yucca Mountain Nuclear Waste Repository, Nye County, Nevada. Letter No. 1-5-90-F-6 from U.S. Fish and Wildlife Service, Reno Field Station, Reno, Nevada.

U.S. Fish and Wildlife Service. 1994. Desert Tortoise (Mojave Population) Recovery Plan. Portland, Oregon. 